\title{
УТВЕРДЖЕННЯ НАЦІОНАЛЬНО-МОВНОЇ СДНОСТІ БАЧВАНСЬКИХ РУСНАКІВ ІЗ ЗЕМЛЯКАМИ НА МАТЕРИКОВІЙ УКРАЇНІ (ПОЧАТОК - ПЕРША ПОЛОВИНА ХХ СТ.)
}

\author{
Юрса Л. В., Негер О. Б.
}

\section{ВСТУП}

У сучасних умовах вивчення історії розвитку та становлення української мови важливе значення має дослідження бачвансько-сримського варіанта української літературної мови, адже, як відомо, наприкінці XX на поч. XXI ст. на крайньому заході українських етнічних земель з'явився антиукраїнський політичний рух так званих неорусинів, і одним із головних елементів їхньої політичної доктрини $є$ спроби довести самостійність так званої русинської мови, а точніше іiї словацького (лемківськопряшівського) та польського (лемківсько-горлицького) варіантів.

Вкрай важливо розуміти, що бачвансько-сримський варіант української мови виник у результаті природної еволюції місцевих говірок українських переселенців, а також за сприяння українських культурних діячів - В. Гнатюка, Г. Костельника, Г. Надя, М. Кочіша, А. Шептицького. Функціонування та розвиток бачвансько-сримського варіанта української мови був єдино можливим способом зберегти українську ідентичність представників найпершої української діаспори, яка $з$ певних історичних причин була відірвана від українських земель.

Як ми вже зазначали, описом бачванської говірки та іiї кодифікації займалися такі науковці, як В. Гнатюк, Г. Костельник, М. Кочіш, О. Горбач, Ч. Бідвел, Г. Надь. Лексика бачванців опрацьована незначною мірою. Необхідно зауважити, що важливим першоджерелом існування бачвансько-сримського варіанту української літературної мови $\epsilon$ словник В. Гнатюка, який доданий до збірки етнографічних матеріалів Р. Керестура та Коцура ${ }^{1}$.

Історія та порівняльний аналіз бачванської говірки подано у праці О. Горбача «Розвоєві тенденції літературної мови бачванськосрімських українців (русинів)»²

${ }^{1}$ Гнатюк В. Словарець менше зрозумілих виразів. Етнографічні матеріали 3 Угорської Руси. Етнографічний збірник. Львів, 1911.

${ }^{2}$ Горбач О. Лексика говірки бачвансько-срімських українців. Науковий збірник музею украӥнської культури в Свиднику. 1969. № 4. Кн. 1. С. 310. 
Лемківсько-пряшівський та русинської мови - результат антиукраїнських сил. Їх метою дезінтеграцію українського вищезазначені варіанти так званої русинської мови постали як альтернатива українській літературній мові, яка, попри численні труднощі, все ж таки існувала та розвивалась на теренах як Чехословаччини, так і Польщі, а також функціонувала у всіх стилях. У зв'язку з цими фактами, незважаючи на термінологічну подібність, русинську мову (руски язик), або бачвансько-сримський варіант української літературної мови, та русинську мову, яка поширена нині в Словаччині, Угорщині та Польщі, не можна ототожнювати, оскільки це абсолютно різні феномени.

У XIX ст. корінні жителі Закарпаття визнали свою мову як частину руської, тобто української мови. Так, відомий історик, мовознавець, фольклорист М. Лучкай у своїй латиномовній «Граматиці...» зазначає: "Unica Dialectus mansit absque Grammatica, et forte corruption, scilicet: Ruthenica, aut Карпато-руска^, quae praeter parvam Russiam, Poloniam, preacipue usu venit in Galicia, Lodomeria, Bukovina, et ab hinc per latus meridionale montium Carpathicorum, seu superiorem Hungariam usque Scepusium, cujusque labii animae in Diaecesi Munkatsiensi et Eperjesiensi, in parteque M. Varadinensi ad medium millionem numerantur" («Без граматики, а може, і без сильного зіпсуття, залишилася єдина мова - руська або карпато-руска, яка вживається, крім Малоросії, Польщі, ще в Галичині, на Волині, на Буковині, і звідси через південний бік карпатських гір, або верхню Угорщину, по Спиш, нею говорить кожен у мукачівському та пряшівському єпископстві, та у частині єпархії Орадя-Маре до пів мільйона осіб») ${ }^{3}$.

У зв'язку із бездієвістю політичного ресурсу культурних осередків України та українців Пряшівщини, Румунії, Польщі склалися всі передумови для того, щоб варіанти української літературної мови функціонували на територіях інших держав. Деякі псевдонауковці продовжують нав'язувати думку, що є окремий русинський народ від українського як самостійна нація.

\section{1. Геополітичні передумови становлення бачвансько-сримського варіанта української літературної мови}

Руски язик як варіант української літературної мови активно функціонує на території Сербії, в автономному краї Воєводина та частково у Хорватії. У 2004 р. відбувся перепис народу, згідно з даними якого в

\footnotetext{
${ }^{3}$ Lutskay M. Slavo-Ruthena Grammatica. Budae. 1830. S.VIII-IX.
} 
Сербії проживає близько 15 тисяч осіб, які називають себе руснаками. Ці поселення компактно проживають у селах Руський Керестур та Коцур. Рідну говірку мешканці Керестура та Коцура називають «руска бешеда», яка походить із південно-лемківського діалекту української мови.

Бачвансько-руську говірку самі носії називають ще «руска бешеда», а ії літературну форму - «руски язик». Цією говіркою послуговуються 25 тисяч русинів (руснаків) Воєводина. Ці мешканці $є$ нащадками українських емігрантів, які переселились із південно-західної Лемківщини (XVIII - XIX ст.) і проживають у містах Новий Сад, Вербас, селах Коцур, Петровці, Руський Керестур, Миклошевці, Беркасово та ін.

У середині XVIII ст. українці, які проживали на території сучасного Закарпаття та Східної Словаччини, у зв'язку із соціально-економічними реформами австрійської імператриці Марії-Терезії, були змушені переселись до сербських сіл Керестур та Коцур. У чужому краї переселенці зуміли зберегти свою мову, хоч вона i зазнала південнослов'янського впливу, зокрема сербського.

Бачванські русини були переселенцями із північно-східної Пряшівщини і Закарпаття та Галичини. Вони переїздили як вільні громадяни, носії греко-католицької віри, зі своїми автохтонними звичаями та традиціями. Переїжджали із північно-східних районів Габсбургської імперії (Жупи Земплин, Шариш, Бордош, Марамарош тощо) на територію сучасної Воєводини, яка була звільнена від турецького поневолення.

У 70-х pp. XVIII ст. також відбулось переселення 8000 запорозьких козаків, які зазнали руйнування Січі та попрямували на Балкани. Такі переселення були спричинені демографічною ситуацією. Адже після завершення австрійсько-турецької війни у 1739 р. у складі австрійської імперії опинилися малозаселені території. Керівництво імперії вирішило долати таку ситуацію шляхом заселення Австро-Угорщини, зокрема чехами, словаками, русинами, румунами та іншими народами імперії.

Також керманичі Австрійської імперії шляхом переселення на орні землі хотіли підвищити дохід країни коштом податків. У 1751 р. почались стихійні переселення українських русинів до Керестура, у 1763 р. - до Коцура. Із Михайлом Мункачі було підписано контракт, у якому зумовлювалося переселення 200 русинських сімей грекокатолицького обряду з верхньо-угорських районів, відомих як “UpperLand" (Горниця), до Керестура ${ }^{4}$.

Русини-українці Коцура та Керестура сповідують греко-католицьку віру і колись мали підпорядкування Мукачівській єпархії, а згодом -

4 Юрса Л. Історія бачвансько-сримського варіанта української літературної мови. Львів, 2015. С. 19-20. 
Великоварадинській єпархії. Ці переселенці мали доступ до церковної літератури, розвивалась церковна школа, в якій викладання проходило руснацькою мовою - варіантом української літературної мови. 31753 p. у Керестурі функціонувала русинська школа, а у Коцурі - з 1765 p.

У 1787 р. відбувся перепис населення, згідно з яким у Керестурі в 303 хатах проживала 431 українська родина, 2191 мешканець, у Коцурі - 318 українська родин, 1915 мешканців.

Переселенці-русини за всю історію свого перебування за межами батьківщини дбали про свої національні та духовні надбання. Так, вони зберігали південно-лемківські говірки, назву «руснак», грекокатолицьку віру, кириличну азбуку.

У 1766-1764 рр. чимала кількість руснаків Керестура та Коцура емігрувала до Нового Саду.

Згідно із переписом 2002 р., у Воєводині ідентифікували себе русинами-українцями 15626 осіб, а на північно-східній території Хорватії - менше 3 тисяч осіб. Після переселення українських руснаків до Бачки та Сриму русинський варіант української літературної мови зазнав значного впливу з боку сербської та хорватської мов.

Русини Керестура та Коцура тривалий час використовували українську редакцію церковнослов'янської мови 3 народнорозмовними вкрапленнями й вважали іiі літературною мовою. Така форма літературної мови функціонувала в ті часи і на території Закарпаття. Необхідно вказати на таку особливість, що діалект, яким послуговуються українські переселенці, значно відрізняється від інших українських говірок. Причиною такої видозміни став той факт, що на структурі мови українських переселенців позначилися впливи суміжних мов - польської, словацької, а згодом і сербської.

Нині є чимало назв на позначення мови русинів Бачки та Сриму, наприклад: бачвансько-русинська, бачвансько-сримська, паннонська мова, бачвансько-руска бешеда, бачваньски руски язик.

\section{2. Мовно-стилістичні особливості бачвансько-русинського діалекту}

Бачвансько-сримський діалект - це мова переселенців у Бачці та Сремі. Бачванська говірка - це варіант української літературної мови із багатьма словацькими, польськими, угорськими, німецькими та сербськими запозиченнями.

О. Горбач зазначає, що він здійснив систематичні записи бачванської лексики в 1953 р. в Р. Керестурі, у 1955 р. -в Керестурі й Беркасові, у 1967 р. - у Вербасі. Науковець порівняв свої записи 3 матеріалами Словничка Володимира Гнатюка i зауважив, що бачванська лексика зазнала помітних змін, зокрема щодо позичень 3 угорської, сербохорватської, німецької й української мов. Велике число угризмів уже забулося (вирази з політично-адміністративної й 
абстрактної лексики). Змінився й склад сербізмів. Від часу Гнатюкових записів керестурська говірка перейняла функцію літературної мови, i ця мова стала й собі впливати через пресу, радіо, школу на лексику, зокрема адміністративну, абстрактну й термінологічну, бачванської говірки: яскраві сербізми не сприймалися гармонійно в мові, i їх замінили нові утворення калькового характеру. 3 мови релігійного культу й учительської інтелігенції перейнято чимало виразних українізмів, крім раніших українських церковнослов'янізмів ${ }^{5}$.

Зрозуміло, що в лексиці бачванців чимала кількість запозичень. Це стало наслідком різних історичних змін, які видозмінювали геополітичну ситуацію переселенців 3 їхніх етнічних земель. Адже чимала кількість запозичень проникла в говірку бачванців ще на території Карпат, зокрема германізми, угризми, румунізми, а після переселення - сербизми, хорватизми та ін.

Однією з особливостей бачвансько-русинського діалекту є те, що він значно відрізняється від інших говірок української літературної мови. Цьому передував ряд причин, зокрема впливи інших мов польської та словацької, адже цей діалект сформувався на основі перехідних українсько-словацьких діалектів південно-західної Лемківщини зі значними впливами сербської мови, а також угорської, польської та німецької мов. Деякі мовознавці визначають бачванськосримський діалект як «слов'янське есперанто».

Науковці зараховують бачвансько-сримську говірку як до західнослов'янських, так і до східнослов'янських мов.

Одним із найбільш важливих аргументів на користь самостійності мови та культури бачвансько-сримських руснаків є їхнє мовлення. Мова бачванських руснаків, або, як вони самі ії називають - руска бешеда, має досить велику різницю із сучасною українською літературною мовою. Але це й не дивно, адже, як слушно зауважує Й. Дзендзелівський, більшість діалектних рис говірок бачванців беруть свій початок у південно-західних говорах української мови, передусім у лемківському діалекті, де вони виникли під впливом суміжних говірок польської та словацької мов ${ }^{6}$.

За науковими спостереженнями Л. Белея, «говірки бачванськосримських руснаків не знають характерного для української мови переходу етимологічних [о], [е] в [i] (вол 'віл', пост 'nicm', стол 'стіл', соль 'сіль') та звичних для української фонетики т.зв. повноголосних

${ }^{5}$ Горбач О. Лексика говірки бачвансько-срімських українців. Науковий збірник музею украӥнської культури в Свиднику. 1969. № 4. Кн. 1. С. 311.

6 Дзендзелівський Й. Мова бачванців як засіб датування явищ лемківського діалект. Руснаци. Русини 1745-1995. Зборнїк роботох зоз медзинародней науковей конференції «Приселєнє и живот Руснацох у Бачкей, Сриму и Славониї 1745-1995». Нови Сад, 1996. С. 7-20. 
блато 'болото', базда 'борозда', браня 'борона', браніи 'боронити', борба 'боротьба' врана 'ворона', злато 'золото’ та ін.; на місці праслов'янських сполук $* d j$, *tj, *kj вживаються як поширені в інших південно-західних говорах української мови $[\partial ж / ж],[u]$ або типові для західносло'янських мов [дз], [u] (меджа 'межа', мачуха, унучка та єдзенє '̈̈жте', помои 'поміч'); праслов'янський *l може переходити або в звичні для української мови звукосполуки [ок/ол] або [лу/ло] (вовк, жовти 'жовтий', колбаси та слунко 'соние'; длобаи 'довбати') тощо»? .

Також важливою складовою частиною бачвансько-русинської мікромови $\epsilon$ те, що вона має широку стилістичну диференціацію, зокрема використовується в художньому, публіцистичному, науковому та офіційно-діловому стилях. Також бачвансько-сримським варіантом української літературної мови видається періодична преса, зокрема: тижневик «Руске слово», дитячий місячник «Заградка», молодіжний місячник «Мак», газета «Шветлосц», вісник «Studia Ruthenica».

Незважаючи на такі факти, за словами М. Мушинки, лінгвісти довго ігнорували русинську мову та літературу. Основною причиною такого ігнорування, на думку М. Мушинки, було те, що «термін “руский”, який у цій мові має точно окреслене значення, важко перекласти на інші мови» ${ }^{8}$.

Варіант української літературної мови, який функціонує на території колишньої Югославії, самі носії називають по-різному: руски язык, руска бешеда, бачванський говір. Цей говір використовує близько 25 тис. руснаків Югославії та Хорватії. Вони є нащадками переселенців 3 автохтонних західноукраїнських земель, які емігрували на Балкани протягом XVIII - XIX ст. Руски язык - це варіант української літературної мови, який утворився під значним впливом східнословацьких говірок. У XVIII ст. перші переселення відбулись із території Закарпатської області до Бачки. Наприкінці XIX ст. - друга хвиля еміграції українців із Галичини.

Нині в Югославії живе приблизно 15 тис. осіб, які $є$ прямими нащадками українських переселенців із західноукраїнських земель ${ }^{9}$.

Тривалий час русини-українці Югославії не мали літературного варіанта своєї мови.

${ }^{7}$ Белей Л. Русинська мова в Сербії та Хорватії. Украӥнська мова. Енициллопедія. Київ : Українська енциклопедія, 2007. 856 с.

8 Мушинка М. Володимир Гнатюк. Життя та його діяльність в галузі фольклористики, літературознавства та мовознавства. Записки наукового товариства ім. Шевченка. Праці філологічної секції. Т. 207. С. 157.

9 Юрса Л. Становлення бачвансько-сримського варіанта української літературної мови на Балканах. Актуальні питання гуманітарних наук : міжвузівський збірник наукових праць молодих вчених Дрогобицького державного педагогічного університету імені Івана Франка. 2019. Вип. 23. Том 3. С. 77-81. 


\section{3. Кодифікатори літературного варіанта української мови на Балканах}

У 1897 p. В. Гнатюк провів тривалу фольклорну експедицію на Бачці, записав та опублікував тексти 430 народних пісень, 220 оповідань, численні анекдоти, а також народне весілля. Це стало поштовхом до кодифікації місцевої бачвансько-сримської говірки та утвердження цієї говірки як специфічного варіанта української літературної мови ${ }^{10}$.

У статті «Словаки чи Русини» В. Гнатюк наводить паралелі та подібності бачванського говору до інших говорів, але при цьому зауважує, що вони не становлять основи тієї літературної мови, якою послуговуються русини Крестура та Коцура ${ }^{11}$.

Лексика бачванців усіяна чималою кількістю запозичень. Зокрема, на думку О. Горбача, чимала кількість лексичних вкраплень проникла ще в Карпатах (германізми, румунізми, угризми), інші знову ж - після переселення в Бачку й Срім (сербохорватизми, угризми, германізми) $)^{12}$.

Найменша кількість запозичень у бачвано-сримську говірку надійшли з румунської мови. Як зауважує О. Горбач, ці запозичення проникли в лемківські говірки з колонізаційною «волоською» хвилею Карпатами в XIV - XVII ст. і стосуються в основному пастушої термінології: балєта (рум. Báligă) “коров’ячка”, бамбух “шлунок корови”, бановач “пожалкувати”"

Також чисельну групу становлять запозичення до бачванської говірки 3 німецької мови. Вони деякою мірою були принесені бачванцями ще 3 Карпат, а частково були перейняті вже під час проживання в Бачці та Сримі. Так, наприклад: акуратни «сумлінний» (н. akkurat), аншлаговач (н. einschlagen) «додавати сірки до забочкованого вина», бай бер/-бель (н. Barbier) «голяр», байка «жилет-корсетик» ${ }^{14}$.

3 угорської мови запозичення в бачвансько-сримську говірку відбуваються ще на теренах Закарпаття, а згодом вже в Бачці: ровка «лисиця» (y. róka «лис»), ройта (y. rojt) «френдзля, торочок, розронтовац, прогайнувати» (y ront «зіпсувати») ${ }^{15}$.

${ }^{10}$ Юрса Л.В. Статус бачвансько-сримського варіанта української літературної мови. Науковий вісник Дрогобицького державного педагогічного університету імені Івана Франка. Серія: «Філологічні науки» (мовознавство). 2016. Том 2. № 5. C. $170-173$.

${ }^{11}$ Гнатюк В. Етнографични матери яли з Угорскей Руси. Розправи и статї о Руснацох Бачкей, Сриму и Словониї. Т. V. Нови Сад : Руске слово. С. 203.

${ }_{12}$ Горбач О. Лексика говірки бачвансько-срімських українців. Науковий збірник музею украӥнської культури в Свиднику. 1969. № 4. Кн. 1. С. 319-320.

13 Там само. С. 320.

14 Там само.

15 Там само. С. 328. 
Також наявні запозичення із сербо-хорватської мови, однак вони вже відбулися після переселення бачванців до Бачки. Запозичення відбулись у зв'язку з тим, що спочатку бачванці жили в одних і тих самих селах, де і серби i, відповідно, запозичення були неодмінним процесом. О. Горбач зазначає, що сербо-хорватська мова «з різних поглядів виявилася ближчою бачванцям, ніж літературний варіант української мови: зокрема своїми не повноголосними формами та збереженням о, е в нових закритих складах (златни, кравар, извор)» ${ }^{16}$.

У 1904 р. відомий громадський діяч, філософ, мовознавець та священик Г. Костельник видає збірку віршів «3 мойого валала», яка стала першим кроком в унормуванні русинської мови як варіанта української літературної мови. За словами Л. Белея, Г. Костельник «заклав основи третього варіанта - бачвансько-сримсько-української літературної мови - руского язика» ${ }^{17}$.

У 1923 р. Г. Костельник видає «Грамматику бачваньско-рускей бешеди», в якій вперше були визначені норми руского язика. Згодом світ побачила мовознавча розвідка Г. Костельника під назвою «О литературном языке югославняских русинов».

У цих працях дослідник утверджує головні фонетичні, граматичні та лексичні норми руської мови Бачки та Сриму. «Граматика...» Г. Костельника складається із шести розділів, які присвячені фонетиці, лексиці, морфології, синтаксису та правопису бачвано-сримського варіанта української літературної мови. Вона стала значним внеском у розвиток гуманітарної науки. Ще однією важливою особливістю мовознавчої спадщини Г. Костельника $\epsilon$ те, що автор став новатором і в кодифікації термінології.

У своїй «Граматиці...» Г. Костельник наголошує на тісній спорідненості бачванської говірки та української літературної мови. Бачванськосримську говірку дослідник, безсумнівно, вважав варіантом української літературної мови, яка має значні польські та словацькі запозичення.

Г. Костельник намагається продемонструвати зв'язок літературного варіанта мови бачванських руснаків-українців та української літературної мови, вказуючи на використання «українських» літер я, ю, $\epsilon, \ddot{i}$, які передають м'якість попередніх приголосних $\mu$ та $ת$, вживання літери $\tau$, а також знака м'якшення. Панівним принципом правопису в текстах Г. Костельника став фонетичний, який сформувався під впливом української літературної мови.

${ }^{16}$ Горбач О. Лексика говірки бачвансько-срімських українців. Науковий збірник музею украӥнської культури в Свиднику. 1969. № 4. Кн. 1. С. 330.

17 Белей Л. Гавриїл Костельник як творець бачвансько-сримського варіанта української літературної мови. Гавриїл Костельник на тлі доби: пошук істини : Збірник наукових праць. Львів - Ужгород : Гражда, 2007. С. 127. 
Дослідник дає коментар щодо знака м'якості «b», який, за його словами, можна було запозичити від хорватів і записувати латинською літерою “j”, але «пре тоти пременки у писовнї ми би ше барз одалєли од общей рускей и од иерковней писовнї, па би зме нє могли легко читаи книжки написани у книжковим (літературним) руско-украинским язику. Прето ше мушине тримаи такей писовнї, хтора за нас згодна, але и як найбаржей зближена ту общей руско-украиньскей писовнї» ${ }^{18}$.

У своїх розвідках Г. Костельник закликав співвітчизників вивчати книжну мову (тобто українську літературну мову), а також зближуватися з нею на письмі. Роздуми та міркування Г. Костельника чітко свідчать про його національне самоусвідомлення та значущість рідної мови: Барз добре видно, же корень намей бешеди рускоукраӥнски; барз вельки вплїв на нєй ше зазначел польски, а словацки уж бул вельо меньши ${ }^{19}$. Важливим твердженням для розуміння цінності накових праць Г. Костельника $\epsilon$ те, що автор намагався ввести «руски язик» у систему загальноукраїнського літературно-мовного ареалу.

Мовознавець всіляко намагався підкреслити свою любов до малої батьківщини, а також прагнення до висвітлення національної української самосвідомості. Так, у поемі «Встань, украӥно! Пісні неволі $\check{u}$ визволення», яка була опублікована у 1918 р., автор закликав до об'єднання всіх українців: Встань, Украӥно!/ Збери дїти свої,/ дай їм імя і власть!/ Я - жерело підземне, скритне -/ Я - найменший в Твоїм обійстю, наймолодший/ Кличу до Тебе:/ Встань, Украйно!/ Виведи дїти свої на світло - [...]/ Мечем обережися/ I пануй над своїми дітьми!../ Встань, Украӥно!

У нарисах «Дзе спада наша бешеда» (1922 р.) і «Наша бешеда» (1937 р.) Г. Костельник торкається питання глотогенезу мови руснаків Югославії, доводить, що бачванська руска бешеда - це діалект української літературної мови, який позначений впливами польської та словацької мов.

У міжвоєнний період активізувалися контакти між бачванськими та галицькими й закарпатськими періодичними виданнями, в яких було опубліковано чимало розвідок про бачванців, їхню культуру, літературну мову, яка функціонувала в бачвансько-сримській говірці.

За часів становлення Карпатської України (1938-1939) бачванськосримські руснаки ведуть активну співпрацю з українцями Закарпаття. Так, однією зі знакових постатей став Діонісій Наряді, який був

18 Костельник Г. Граматика бачваньско-рускей бешеди. Проза на руским літературним язику. 1. Вид. Нови Сад : Руске слово : Завод за культуру войводянских Руснацох, 2011. С. 245-246.

19 Костельник Г. Наша бешеда. Проза на бачванско-сримским руским літературним язици. С. 186. 
нащадком колишніх переселенців i повернувся на батьківщину, обійнявши посаду Апостольського адміністратора Карпатської України. Знаковою історичною подією став той факт, що бачванські русини зібрали 15 тис. динарів для розбудови Карпатської України. Після трагедії, яка сталась у березні 1939 р. на Красному полі (Карпатська Україна була окупована фашистською армією Адольфа Гітлера та проведені жорстокі репресії щодо місцевих українців), чимала кількість симпатиків Карпатської України знайшли прихисток у своїх земляків на Бачці.

У міжвоєнний період сформувалися два протилежні погляди щодо чинності та автохтонності руської мови переселенців на Балканах. Прихильники одного із поглядів вважали, що руська мова $\epsilon$ варіантом української літературної мови і має функціонувати на заселених землях як літературна мова. Інші ж тяжіли до течії панславізму. На думку протилежного крила дискусій, русинська мова була похідною від російської і прихильники цієї ідеї хотіли бачити своєю літературною мовою карпатсько-русинський варіант або російську мову. Москвофіли проводили активну політику проти народно-розмовного варіанта використання мови та пропагували ввести язичіє. Свою діяльність москвофіли Бачки та Сриму закріплюють за допомогою заснування культурно-просвітницьких організацій, які вони почали відкривати 3 1933 р., а вже у 1934 р. започаткували вихід періодичного видання «Заря» (з 1936 р. - «Русска заря»). Цими виданнями вони започаткували рух проти національно зорієнтованих руснаків Бачки та Сриму: "...нашу рускоси, котру зме пріяли од наших оцох, од наших руских дїдох, бра німе од поджемних, тайних нападох ткз. «Українизма» зоз шицкихи нашими силами и могучими средствіями» ${ }^{20}$. Вони пропонують вживати назву Україна, яка на той час була на піку популярності у слововжитку бачванських руснаків, як «єдну богату русску обласи(край) велькей и моцней России».

У повоєнні часи москвофільські активісти влилися в соціалістичні органи Югославії, і вже у цій іпостасі намагалися зросійщити життя руснаків Бачки та Сриму. Проросійські представники прагнули всіляко дискримінувати бачванських руснаків та проводили активну антиукраїнську політику, зокрема від конфлікту, який відбувся між I.В. Сталіним та Й. Тіто у 1948 р., до зв'язків 3 «українськими націоналістами» Німеччини, Канади, Англії, США. Але попри складну політичну ситуацію, яка склалася на території соціалістичної Югославії, місцеві українофіли змогли зберегти свою національно спрямовану українську свідомість та протистояти всіляким антиукраїнським рухам.

${ }^{20}$ Олеяров Н.Д. Рускосц чи «українство?» Заря. 1934. 27 мая. 
Напередодні розпаду Югославії на теренах Сербії утворилися дві організації - Союз русинів і українців Югославії та «Руска матка», які об’єднували так званих «українофілів» та «автохтонів». Це призвело до того, що «колишні бачвансько-сримські москвофіли та їхні симпатики у союзі з сербськими націонал-комуністами Слободана Мілошевича під личиною неорусинства витворили антиукраїнську платформу, що й засвідчило заснування «Руської матки» та діяльність ii активістів Дюри Папуги, Любомира Медєші, Наталії Дудаш та ін. Щоб замаскувати справжнє призначення «Руської матки» та зробити ії ідеї привабливими для широких верств руснаків Сербіï, iii активісти не втомлювалися наголошувати на власному європоцентризмі» ${ }^{21}$, бо «нібито після Другої світової війни Європа визнала право русинів на власну державу» 22 .

Ще однією знаковою постаттю у формуванні національної свідомості руснаків Балкан став Гавриїл Надь, який народився у м. Старий Врбас - Воєводина. Учений написав чимало праць, які присвячені вивченню та розвитку руської мови, зокрема ії граматичних, правописних та лексичних особливостей, а також методиці викладання мови, досліджував історію руської мови.

У праці «3 нашого правопису» 1950 р. Г. Надь розглянув проблемні питання у сфері орфографії.

Ще одним відомим кодифікатором бачвансько-сримської говірки як варіанта української літературної мови став Микола Кочиш. Народився науковець у с. Дюрдево - Воєводина. Він $\epsilon$ автором понад 20 статей, які врегульовують проблемні питання кодифікації руської мови.

М. Кочіш публікував праці, які характеризують проблеми правопису, лексики, граматики та ономастики югославських русинів. Він автор таких мовознавчих праць, як «Мацеринска бешеда. Граматика» $(1965,1967,1968)$, «История: словник терминох за основну школу» (1970), «Правопис руского язика» (1971), «Приручни терминологийни словник сербскогорватско-руско-українски» (1972), «Граматика руского язика за I-II класу гимназиї» (1974), яка побачила світ завдяки рецензентові А. Чипкарю.

Нині літературна мова русинів-українців Бачки та Сриму визнана однією з офіційних мов Воєводини (Сербія). Також, як офіційна мова, вона використовується в середовищі жителів Руського Керестура, Коцура, Вербаса, Бачки, Нового Саду та ін.

${ }^{21}$ Белей Л. «Русинський» сепаратизм: націєтворення in vitro. Київ : Темпора, 2017. С. 150.

${ }^{22}$ Там само. 
За словами М. Мозера, русини є «власне українцями, що споконвіку були «русинами-українцями», але 3 різних досить складних $\mathrm{i}$ багатоманітних причин (..) опинилися осторонь тих новітніх націотворчих процесів, що їх останній етап розпочався в другій половині XIX ст.» ${ }^{23}$.

Знаний дослідник історії, культури та літератури руснаків Балкан М. Цап переконаний у тому, що руснаки Югославії мають глибоку культурно-національну традицію із русинами Карпат: «3 уключованьом Руснацох и Сриму до общекултурних и националних цекох закарпатських Русинох стредком XIX столїтия, почина процес котри условно наволуєме предистория культурно-националного пре породу Руснацох нєшкайшей Югославиї. Як познате, початки того пре породу звичайно ше вяже за 1890 рок и видаванє Русского соловея Михайла Врабеля, першей книжки на язику бачванско-сримских Руснацох, алє зачатки културней активносци, през свидомосц о припаданю гу ширшей националней заєднїци Русинох (Українцох) з обидвох бокох Карпатох, маю глибшу традицію» ${ }^{24}$.

Із 1949 р. на території міста Новий Сад діє русинська радіоредакція, яка передає інформаційні та музичні програми, а також на філософському факультеті університету понад тридцять років функціонує Відділ русиністики.

У 1975 р. створена русинська телеорганізація «Новий Сад», яка транслює інформаційні, культурні та фольклорні передачі. У Руському Керестурі функціонує гімназія, навчання в якій проводиться русинською мовою.

Прибічник українськості в науково-культурному розвитку бачвансько-сримських руснаків Ю. Тамаш наголошує на тому, що «хай у русинській краплині роси відзеркалюється подоба українського моря, щоб не зникло воно, як роса, в російському імперському океані» ${ }^{25}$.

\section{ВИСНОВКИ}

Можна 3 певністю стверджувати, що руски язик - це варіант української літературної мови, а русини є частиною українського народу. Так склалося історично, що українські руснаки проживають на

\footnotetext{
${ }^{23}$ Мозер М. Причинки до історії української мови. Вінниця : Нова Книга, 2011. C. 367.

${ }^{24}$ Цап М. На жридлох духовносци: огляди 3 историї рускей литератури и култури. Нови Сад : Руске слово, 2014. С. 9.

${ }_{25}$ Тамаш Ю. Улога Русинох у европейскей цивилизации. Руснаци. Русини 1745-1995. Зборнїк роботох зоз мудзинародней науковей конференции «Приселєнє и живот руснацох у Бачкей, Сримуу и Славониї 1745-1995». Нови Сад, 1996. С. 340.
} 
різних територіях, але етнічно та духовно є спорідненими і вважають себе однією нацією - українською.

Процес становлення та розвитку мови русинів Балкан був доволі звивистим та насиченим різноманітними подіями, що пливали на його розвиток. Головною цінністю бачвансько-сримських руснаків $\epsilon$ те, що вони зуміли зберегти свою автентику, мову, культуру та колорит.

Неорусинський рух зародився в гирлі місцевих москвофілів та мадярофілів, які намагались протидіяти національним українським віянням, що активно впроваджувались на територіях Балкан, де компактно проживали українські переселенці.

Неорусинський рух - це антиукраїнський напрям, який може призвести до геополітичних змін України.

Серед лінгвістичної групи руснаків України та українських переселенців спостерігається збіг рідної та етнічної української мови. III представникам притаманний високий рівень володіння своєю етнічною мовою.

Перспективу подальших досліджень ми вбачаємо у вивченні змін крізь призму лінгвістичної ідентифікації руснаків, які відбуваються у процесі соціальних трансформацій, зокрема: політичної конфронтації, міграційних процесів, а також культурологічних уподобань народу.

Антиукраїнський неорусинський рух має дезінтеграційне спрямування. Неприпустимо надавати змогу висувати гіпотези та псевдонаукові теорії про існування русинів як окремої нації в Закарпатській області України. Такі прояви ми зараховуємо до рангу сепаратистських дій, які нівелюють історичні традиції, здійснюють заміну понять. Усе це потрібно розглядати не тільки на мовному рівні, але i на політичному, адже нехтування може призвести до вкрай негативних наслідків.

Державні органи Закарпаття та України загалом лояльно ставляться до неорусинського руху, а часом i співпрацюють із його представниками. Це несе велику загрозу не тільки для лінгвістичного світу, але й для територіальної цілісності держави. Потрібно раз і назавжди заборонити використовувати самоназви русин/руський для найменування нового слов'янського народу, якого немає в природі i який утворений шляхом заміни уявлень, понять, маніпуляційними схемами та сепаратистськими намірами.

Зрозуміло, що для підтримки та розвитку псевдорухів вкладаються чималі кошти зацікавлених осіб як у середині держави, так і поза іiі межами. Їх мета - дезорієнтація суспільства та асиміляція українських національних меншин за кордоном.

Усвідомлення себе як нації, відчуття своєї самостійності та індивідуальності $€$ важливим складником подальшого існування та 
розвитку. Лінгвістичні норми процесу мовлення та його сприймання $€$ однією з особливостей подальшого розвитку мови, народу країни. Тому вкрай важливо підтримувати культурну приналежність народу на всіх щаблях (мовних, політичних тощо). Створення дієвої мовної політики, а також законодавчої бази може врегулювати будь-які прояви псевдорухів, що призводять до сепаратистських чи асимілятивних наслідків.

Поняття «русинська нація» - це псевдонаукова гіпотеза, яка спрямована на дезінтеграцію суспільства. За допомогою маніпуляційних схем здійснюється заміна понять.

Таким чином, із впевненістю можна стверджувати, що русинська мова - це фікція, яка не має під собою жодного наукового чи історичного підгрунтя. Теорія русинства не має жодного наукового обгрунтування і ніяким чином не пов'язана $з$ культурою автохтонних мешканців історичного Закарпаття, а також переселенців, які компактно проживають за межами України. Ця доктрина побудована на технологічно-маніпуляційному підході і має конкретне завдання створити ілюзію про існування самостійного русинського народу.

\section{АНОТАЦІЯ}

Метою дослідження є окреслення проблеми історико-лінгвістичного розвитку бачвансько-сримських руснаків початку XX ст. Автори розглядають такі аспекти національно-мовного розвитку українських русинів колишньої Югославії, як етнодемографічні тенденції, розвиток національної культури, мови, релігії, творення ідеологічних громад та організацій, функціонування періодичних видань. Окрема увага звертається на кодифікацію національно-мовної сторони, яка унеможливлює спекуляції щодо окремішності русинської народу та русинської мови від українців та української літературної мови. Констатується роль еліти бачвансько-сримських русинів, які стали основоположниками та фундаторами етнокультурної приналежності руснаків Балкан. Методологія статті базується на історичному та структурно-функціональному підході. Автори використали методику статистичного аналізу результатів переписів населення Керестура та Коцура 1787 р., міграційних показників рухливості української національної меншини на територію Балкан із Закарпаття та Галичини. Наукова новизна полягає у використанні структурно-функціонального методологічного підходу до вивчення національно-громадського представництва української етнічної групи на деяких територіях Балкан (Бачка, Срим, Керестур, Коцур) на початку XX ст. Бачвансько-сримські руснаки змогли зберегти та розвивати свою національно-етнічну належність у складних геополітичних ретроспективах. 
Це демонструється в лінгвістичних здобутках, фольклористичних експедиціях, збереженні традицій та культури, розширення діяльності громадських організацій, україністичних студій на базі шкіл та факультетів.

\section{ЛІТЕРАТУРА}

1. Белей Л. Гавриїл Костельник як творець бачвансько-сримського варіанта української літературної мови. Гавриїл Костельник на тлі доби: пошук істини : Збірник наукових праць. Львів - Ужгород : Гражда, 2007. С. 127.

2. Белей Л. Русинська мова в Сербії та Хорватії. Українська мова. Енциклопедія. Київ : Українська енциклопедія, 2007. 856 с.

3. Белей Л. «Русинський» сепаратизм: націєтворення in vitro. Київ : «Темпора», 2017. 392 с.

4. Костельник Г. Граматика бачваньско-рускей бешеди. Проза на руским літературним язику. 1. Вид. Нови Сад : Руске слово : Завод за культуру войводянских Руснацох, 2011. С. 245-246.

5. Гнатюк В. Словарець менше зрозумілих виразів. Етнографічні матеріали з Угорської Руси. Етнографічний збірник. Львів, 1911.

6. Горбач О. Лексика говірки бачвансько-срімських українців. Науковий збірник музею украӥнської культури в Свиднику. № 4. Кн. 1. 1969. С. 310.

7. Дзендзелівський Й. Мова бачванців як засіб датування явищ лемківського діалект. Руснаци. Русини 1745-1995. Зборнїк роботох зоз медзинародней науковей конференції «Приселєнє и живот Руснацох у Бачкей, Сриму и Славониї 1745-1995». Нови Сад, 1996. С. 7-20.

8. Костельник Г. Наша бешеда. Гавриїл Костельник. Проза на бачванско-сримским руским літературним язици. С. 186.

9. Мозер М. Причинки до історії української мови. Вінниця : Нова Книга, 2011. 848 с.

10. Мушинка М. Володимир Гнатюк. Життя та його діяльність в галузі фолкльористики, літературознавства та мовознавства. Микола Мушинка. Записки наукового товариства ім. Шевченка. Праиі філологічної секиії. Т. 207. С. 157.

11. Олеяров Н.Д. Рускосц чи «українство?». Заря. 1934. 27 мая.

12. Тамаш Ю. Улога Русинох у европейскей цивилизации. Руснаци. Русини 1745-1995. Зборнїк роботох зоз мудзинародней науковей конференции «Приселєнє и живот руснацох у Бачкей, Сримуу и Славониї 1745-1995». Нови Сад, 1996. С. 340.

13. Цап М. На жридлох духовносци: огляди 3 историї рускей литератури и култури. Нови Сад : Руске слово, 2014. 129 с. 
14. Юрса Л. Історія бачвансько-сримського варіанта української літературної мови. Львів, 2015. 175 с.

15. Юрса Л. Становлення бачвансько-сримського варіанта української літературної мови на Балканах. Актуальні питання гуманітарних наук: міжвузівський збірник наукових праць молодих вчених Дрогобицького державного педагогічного університету імені Івана Франка. Вип. 23. Том 3. Дрогобич, 2019. С. 77-81.

16. Юрса Л.В. Статус бачвансько-сримського варіанта української літературної мови. Науковий вісник Дрогобицького державного педагогічного університету імені Івана Франка. Серія «Філологічні науки» (мовознавство) : збірник наукових праць. Том 2. № 5. Дрогобич, 2016. C. 170-173.

17. Michaelis Lutskay. Slavo-Ruthena Grammatica. Budae. 1830. S. VIII-IX.

\section{Information about the authors:} Yursa L. V.,

Candidate of Philological Sciences, Associate Professor at the Department of Ukrainian Applied Linguistics Ivan Franko National University of Lviv 1, Universytetska str., Lviv, 79000, Ukraine

Neher O. B.,

Candidate of Philological Sciences, Associate Professor at the Department of Ukrainian Applied Linguistics

Uzhhorod National University

3, Narodna Sq., Uzhhorod, 88000, Ukraine 